\title{
Analysis of the environmental impact generated by backyard swine production in Tepetlán, Veracruz, Mexico
}

\author{
Solís-Tejeda, Miguel Á. ${ }^{1}$; Lango-Reynoso, Fabiola ${ }^{1^{*}}$; Castañeda-Chávez, María del R. ${ }^{1}$; \\ Ruelas-Monjardin, Laura C. ${ }^{1}$ \\ ${ }^{1}$ Tecnológico Nacional de México/Instituto Tecnológico de Boca del Río. Carretera Veracruz-Córdoba km 12; \\ Boca del Río, Veracruz, México. C. P. 94290. \\ * Corresponding author: fabiolalango@bdelrio.tecnm.mx
}

\begin{abstract}
Objective: To identify and estimate waste production, water consumption and production practices of backyard swine farms at the municipality of Tepetlán; Veracruz, Mexico, to foresee the possible influences on the environment and generate information that promotes new public environmental policies adapted to small producers.

Methodology: 36 backyard livestock production units were identified and studied in Vicente Guerrero and Alto Tío Diego by a census in which structured surveys were applied to obtain data; the results were analyzed by descriptive statistics. The maximum pollutant potential of the load with the installed infrastructure was estimated.

Results: We registered 503 swine heads of diverse zootechnical functions, mainly from the Landrace breed, in 36 studied farms, 54.7\% of idle infrastructure was identified. We found that about three tons of excreta are produced per day between the towns of Vicente Guerrero and Alto Tío Diego, from which 78\% are dumped into the municipal drainage. The average water consumption per unit of livestock production was $132.2 \mathrm{~L}$ and for each unit of animal population $28.5 \mathrm{~L}$, with a standard deviation of $32.2 \mathrm{~L}$ per animal population unit. This research also provides information on the feeding and production practices of the animals. It was possible to estimate the volume of swine excreta generated in the assessed localities. However, it is necessary to quantify organic matter, nitrogenous products, phosphorus, and total and fecal coliforms.

Conclusions: It is important to quantify and regulate the generated waste by this livestock activity, to take corrective and regulatory decisions, to establish solutions that protect natural resources without harming the economy of the small producer.
\end{abstract}

Keywords: swine production, animal population unit, water and soil pollution.

Citation: Solís-Tejeda, Miguel Á., LangoReynoso, Fabiola, Castañeda-Chávez, María del R., \& Ruelas-Monjardin, Laura C. (2021). Analysis of the environmental impact generated by backyard swine production in Tepetlán, Veracruz, Mexico. Agro Productividad, 14(\#). https:// doi.org/10.32854/agrop.v14i6.1875

Editor in Chief: Dr. Jorge Cadena Iñiguez

Estimated publication date: July 2021

This work is licensed under a Creative Commons Attribution-NonCommercial 4.0 International license

\section{INTRODUCTION}

Mexico produces almost 18 million head per year, from which, 1,751,183 heads were produced at the state of Veracruz during 2019, ranking fourth nation-wise, after Jalisco, Sonora and Puebla (SIAP, 2020b). It is a profitable activity, generating significant profits for farmers. As a result, the number of people in the Mexican countryside who engage in swine farming increases each year.

In Mexico, three swine production systems are recognized: technified, semitechnified and backyard systems (Mariscal, 2007). The first two have a defined geographical distribution and are registered and regulated by the authorities; on other hand, the backyard system is present in all the country, more common in Veracruz, which many small producers with land plots of less than one hectare.

The economic activity of breeding and fattening swine, in addition to contributing to the country's gross domestic product, produce large volumes of wastewater with urine, excreta, the runoffs of washing of production units, uneaten feed and various polluting liquids, which are usually not properly handled, and their final disposal 
are soils, urban wastewater, and/or surface bodies of water near the production units (Mateo et al., 2019; Sandoval-Herazo et al., 2020).

Swines' wastewater enters a high concentration of nutrients in surface waters. This has been increasing notably in recent decades. The degradation of water quality can cause a potential impact on health risks, in addition to the typical negative effects caused to the environment (De la Mora et al., 2014). The $\mathrm{NH}_{3}$ emitted by swine farms is deposited close to where it is produced, thus contributes to the eutrophication and acidification of ecosystems (Liu et al., 2013), as well as to the reduction of biodiversity (Clark and Tilman, 2008). Swine production accounts for approximately 15\% of the worldwide $\mathrm{NH}_{3}$ emissions associated with livestock (Olivier et al., 1998).

The official Mexican Norm (NOM-001-ECOL-1996) is an instrument to regulate the pollution of national waters by various activities, including livestock; compliance with it is carried out by the competent authority for identified livestock units, mainly those with a large number of animal units (AU). At the same time, the Ley de Organizaciones Ganaderas (law for livestock organization) in Mexico considers as producers those which have a minimum inventory of five animal units, for swines the equivalence corresponds to 15 swine's Regulations of the Livestock Organizations Law (Reglamento de la Ley de Organizaciones Ganaderas, 1999). This leaves out backyard producers, who are not identified and do not register their inventories with the authority and are not regulated.

Tepetlán municipality is in the center of the state of Veracruz, Mexico. It is a small municipality of just over $83 \mathrm{~km}^{2}$, its population is 9429 people; it has 29 localities, of which 28 are rural and one urban (Subsecretaria de Planeación, 2018). Tepetlán is dedicated to agricultural activities such as sugarcane and lemon crops, and livestock such as dairy and pork production; however, there are no industrialized or technified farms and is therefore not listed as a municipality with high animal production. Yet, it has a large number of backyard producers, with which it reached a production of 157.37 tons of live swine during 2019, with a recorded local production value of $\$ 4,482,039.00$ Mexican pesos (SIAP, 2020a).

Given the above, it is important to identify backyard swine production units, in addition to estimating their waste production, water consumption and practices production to foresee possible impacts on the environment and generate information that promotes new environmental public policies adapted to small producers.

\section{MATERIALS AND METHODS}

The present study took place in Tepetlán municipality, at Vicente Guerrero and Alto Tío Diego localities, where there is a high production of backyard farm swine (FAOCC, 2020).

For this research, support was requested from the General Directorate of Rural Development (Dirección General de Desarrollo Rural) from the Secretary of Agricultural, Rural and Fishing Development (Secretaria de Desarrollo Agropecuario, Rural y Pesca), and from the Autonomous Foundation of Organizations of Farmers and Settlers A. C. 
(Fundación Autónoma de Organizaciones de Campesinos y Colonos A. C. FAOCC) to identify the backyard swine production units in the included localities in this study. It should be noted that since these are not registered by the authorities, there is not an exact number of backyard swine farms within these localities.

The livestock production units (LPU) considered for this study are backyard farms, with less than five animals, with basic infrastructures, such as block or brick swine pens, and, in some cases, basic production equipment, mainly maternity cages.

Once the LPU's were identified through the census, surveys were applied to identify the number of animals at the time of the assessment, maximum productive capacity, infrastructure and equipment, water supply and final disposal, waste disposal, in addition to identifying the environmental knowledge of the producers.

Subsequently, the number of animal population units (APU), the generation of excreta and the amount of wastewater were estimated.

The number of APU's helps to compare between LPU's dedicated to breeding and those dedicated to fattening; it is determined by their equivalence, one APU is equivalent to $100 \mathrm{~kg}$ of live swine (Méndez et al., 2009).

To calculate the biomass in kilograms, the average weights of the animals were taken, considering their zootechnical function. The total biomass of the swine on the assessed farms was obtained and finally divided by 100, to obtain the number of total UPA's (Méndez et al., 2009). A total of $214 \mathrm{~kg}$ was recorded for bellies and sires, $16 \mathrm{~kg}$ for weaning animals and $75 \mathrm{~kg}$ for fattening animals.

Taking values from Drucker et al. (2004) and Méndez et al. (2009), swine excreta production per APU was determined to be $9 \mathrm{~kg} \mathrm{~d}^{-1}$ for sow and hog, $8.6 \mathrm{~kg} \mathrm{~d}^{-1}$ for weaning and $7 \mathrm{~kg} \mathrm{~d}^{-1}$ during fattening.

To estimate the water consumption of the APU's, each producer was surveyed during a visit; in some cases, water use records were presented; finally, the sum of the water presumably consumed in backyard swine production was added up.

To complement the data, unstructured interviews were conducted using the selective snowball sampling technique used by Di Lorio et al. (2020), where the different points of view of backyard production could be analyzed.

\section{RESULTS AND DISCUSSION}

We identified and analyzed $n=36$ backyard swine farms, 23 located in the town of Vicente Guerrero and 13 in Alto Tío Diego. The livestock herd present at the time of the census is described in Tables 1 and 2; which is mainly of the Landrace breed, chosen by the producers for the good performance of the sows, with some Pietrain sires. All farms had idle infrastructure, so it was necessary to determine the maximum APU's for each facility, finding an idle capacity of $54.7 \%$.

A record of the daily and average water consumption per APU was obtained. The sum of the daily water consumption in the assessed farms was $6.09 \mathrm{~m}^{3}$, with an average of 169.2 L used by each LPU daily, and 28.5 L of water consumed per day by each PAU, with a population average of $14.38 \mathrm{~L} / \mathrm{PAU}$; the standard deviation of water consumption 
per UPA with respect to the mean reached 33.2 L / PAU on average. The calculation of water consumption, if the facilities were at 100\% capacity, was estimated to be $24.1 \mathrm{~m}^{3}$.

Table 1. Summary of information collected in Vicente Guerrero, Veracruz, Mexico.

\begin{tabular}{|c|c|c|c|c|c|c|c|c|c|c|}
\hline No. & $\begin{array}{l}\text { Breeding } \\
\text { sows }\end{array}$ & Stallions & $\begin{array}{c}\text { Fatteners } \\
\text { pig }\end{array}$ & Piglet & APU & $\begin{array}{c}\text { APU } \\
\text { maximum }\end{array}$ & $\begin{array}{l}\text { Dropping } \\
\mathbf{d}^{-1}\end{array}$ & $\begin{array}{c}\text { Dropping d }^{-1} \\
\text { maximum } \\
\text { capacity }\end{array}$ & $\begin{array}{c}\text { Water } \\
\text { L/d/LPU }\end{array}$ & $\begin{array}{l}\text { Water } \\
\text { L/APU }\end{array}$ \\
\hline 1 & 8 & 0 & 25 & 14 & 38.1 & 88.5 & 302.1 & 303.1 & 200 & 5.2 \\
\hline 2 & 0 & 0 & 5 & 0 & 4 & 9.9 & 28 & 30 & 200 & 50 \\
\hline 3 & 3 & 0 & 13 & 0 & 16.4 & 34.5 & 126.8 & 129.8 & 200 & 12.2 \\
\hline 4 & 0 & 0 & 0 & 8 & 1.2 & 12 & 10.3 & 14.3 & 200 & 166.7 \\
\hline 5 & 1 & 0 & 3 & 12 & 6.2 & 6.2 & 50.3 & 55.3 & 200 & 32.3 \\
\hline 6 & 0 & 0 & 4 & 0 & 3.2 & 12 & 22.4 & 28.4 & 200 & 62.5 \\
\hline 7 & 1 & 0 & 25 & 0 & 22 & 36 & 158 & 165 & 100 & 4.5 \\
\hline 8 & 2 & 0 & 0 & 11 & 5.65 & 19.2 & 50.2 & 58.2 & 100 & 17.7 \\
\hline 9 & 0 & 0 & 2 & 0 & 1.6 & 5.5 & 11.2 & 20.2 & 20 & 12.5 \\
\hline 10 & 3 & 0 & 18 & 10 & 21.9 & 38.5 & 167.7 & 177.7 & 200 & 9.1 \\
\hline 11 & 2 & 0 & 0 & 6 & 4.9 & 28.5 & 43.7 & 54.7 & 100 & 20.4 \\
\hline 12 & 0 & 0 & 10 & 0 & 8 & 23.7 & 56 & 68 & 200 & 25 \\
\hline 13 & 1 & 0 & 25 & 0 & 22 & 34.5 & 158 & 171 & 90 & 4.1 \\
\hline 14 & 6 & 2 & 9 & 11 & 24.8 & 53.7 & 208.6 & 222.6 & 200 & 8 \\
\hline 15 & 1 & 0 & 7 & 0 & 7.6 & 23.5 & 57.2 & 72.2 & 100 & 13.2 \\
\hline 16 & 0 & 0 & 3 & 0 & 2.4 & 25 & 16.8 & 32.8 & 100 & 41.7 \\
\hline 17 & 1 & 0 & 30 & 0 & 26 & 59.5 & 186 & 203 & 400 & 15.4 \\
\hline 18 & 3 & 0 & 15 & 30 & 22.5 & 22.5 & 176.7 & 194.7 & 200 & 8.9 \\
\hline 19 & 2 & 1 & 0 & 0 & 6 & 21 & 54 & 73 & 200 & 33.3 \\
\hline 20 & 4 & 0 & 0 & 12 & 9.8 & 16 & 87.5 & 107.5 & 400 & 40.8 \\
\hline 21 & 0 & 0 & 0 & 10 & 1.5 & 23.7 & 12.9 & 33.9 & 200 & 133.3 \\
\hline 22 & 3 & 0 & 8 & 0 & 12.4 & 25 & 98.8 & 120.8 & 200 & 16.1 \\
\hline \multirow[t]{2}{*}{23} & 2 & 1 & 10 & 0 & 14 & 31 & 110 & 133 & 200 & 14.3 \\
\hline & 43 & 4 & 212 & 124 & 282.2 & 650.1 & 2193.2 & 2469.2 & 4210 & \\
\hline
\end{tabular}

Seventy-two-point two percent of the farmers discharge their wastewater into the municipal sewage system; 22.2\% into crops, such as sugarcane, corn, or livestock pastures; while only 5.6\% have septic tanks. Only 5.6\% have a septic tank. Twenty-two percent of the farmers report treating the generated solid waste, mainly as fertilizer for sugarcane crops and pastures. Regard antibiotics usage, 92\% continuously use them in the production process, especially tetracyclines, and 36\% use hormones, mainly oxytocin, to support the females during calving; only $67 \%$ use these drugs by prescription.

Only 5.5\% of the producers stated that they provide swine with a diet based on agricultural by-products, mainly corn and chayote. Eleven point one percent use balanced feed as a base and supplement with agricultural products; while 83.3\% provide a commercial diet based on products containing ground cereals, oilseed pastes, vitamins, molasses, amino acids and minerals. 
Table 2. Summary of information collected in Alto Tío Diego.

\begin{tabular}{|c|c|c|c|c|c|c|c|c|c|c|}
\hline No. & $\begin{array}{l}\text { Breeding } \\
\text { sows }\end{array}$ & Stallions & $\begin{array}{c}\text { Fatteners } \\
\text { pig }\end{array}$ & Piglet & APU & $\begin{array}{c}\text { APU } \\
\text { maximum }\end{array}$ & $\begin{array}{l}\text { Dropping } \\
\mathbf{d}^{-1}\end{array}$ & $\begin{array}{c}\text { Dropping } d^{-1} \\
\text { maximum } \\
\text { capacity }\end{array}$ & $\begin{array}{c}\text { Water } \\
\text { L/d/LPU }\end{array}$ & $\begin{array}{l}\text { Water } \\
\text { L/APU }\end{array}$ \\
\hline 1 & 2 & 0 & 6 & 0 & 8.8 & 22.9 & 69.6 & 182.7 & 200 & 22.7 \\
\hline 2 & 0 & 0 & 8 & 0 & 6.4 & 9.6 & 44.8 & 67.2 & 200 & 31.3 \\
\hline 3 & 0 & 0 & 7 & 0 & 5.6 & 8 & 39.2 & 56 & 200 & 35.7 \\
\hline 4 & 0 & 0 & 2 & 0 & 1.6 & 2.4 & 11.2 & 16.8 & 40 & 25 \\
\hline 5 & 0 & 0 & 6 & 0 & 4.8 & 8 & 33.6 & 56 & 50 & 10.4 \\
\hline 6 & 0 & 0 & 9 & 0 & 7.2 & 8.8 & 50.4 & 61.6 & 150 & 20.8 \\
\hline 7 & 0 & 0 & 4 & 0 & 3.2 & 8 & 22.4 & 56 & 150 & 46.9 \\
\hline 8 & 0 & 0 & 9 & 0 & 7.2 & 12 & 50.4 & 84 & 150 & 20.8 \\
\hline 9 & 0 & 0 & 9 & 0 & 7.2 & 28.8 & 50.4 & 201.6 & 100 & 13.9 \\
\hline 10 & 1 & 0 & 22 & 0 & 19.6 & 32 & 141.2 & 224 & 300 & 15.3 \\
\hline 11 & 3 & 0 & 4 & 0 & 9.2 & 28 & 76.4 & 196 & 140 & 15.2 \\
\hline 12 & 2 & 0 & 10 & 9 & 13.3 & 20 & 103.6 & 148 & 100 & 7.5 \\
\hline \multirow[t]{2}{*}{13} & 1 & 0 & 6 & 0 & 6.8 & 8 & 51.6 & 56 & 100 & 14.7 \\
\hline & 9 & 0 & 102 & 9 & 100.9 & 196.5 & 744.8 & 1405.9 & 1880 & 484.8 \\
\hline
\end{tabular}

All producers consider that water is a limiting factor for production in this municipality, but $88.8 \%$ do not see backyard swine farming as a problem for water resources and are unaware of the swine excrement might have on the environment. No producer has sanitary infrastructure for their waste treatment.

At the time of the census, low pork production was recorded for the infrastructure installed by backyard producers; the instruments applied indicate that this is a consequence of the rise in the costs of balanced feed since it represents $80 \%$ of the costs in backyard swine (Méndez-López et al., 2016). However, backyard producers do not usually plan their production, and state they usually need a greater amount of infrastructure, such as pens for certain production periods.

It was possible to estimate a high current production of swine manure in very small localities, which if not correctly treated, can cause negative environmental impacts, such as soil and water contamination and generation of gases that potentiate the greenhouse effect; in addition, when waste is dispersed on land, it causes unhealthy situations due to bad odors, among others; which decreases the quality of life for people; as some local inhabitants mention (Osejos et al., 2018).

In the municipality, water is a scarce resource, it has 40 water supply sources, and a mean daily volume of 3.4 thousand of $\mathrm{m}^{3}$ of water (Subsecretaria de Planeación, 2018). The recorded water usage for backyard swine was 28.5 L per day per APU on average, very close to that reported by Drucker et al. (2004) estimate of $35 \mathrm{~L}$ per day per APU for small farms; however, considering the high standard deviation, there were backyard units with consumption exceeding $130 \mathrm{~L}$ per day per APU.

Regard the management of backyard production waste, the only recorded treatment for solid waste and wastewater was as fertilizer, which is not healthy for the 
environment, as ammonium production can cause eutrophication and acidification of ecosystems (Liu et al., 2013).

The common process to dispose of excreta and urine in the sampled farms was through drainage, which is not adequate management, as the municipality only has one wastewater treatment plant, with a basic capacity of $0.5 \mathrm{~L} \mathrm{~min}^{-1}$ (Subsecretaria de Planeación, 2018).

Therefore, we agree with the analysis made by Pérez (2000) that there is an inefficient use of water, with low or null pollutant removal for activity in constant growth; we also agree that an environmental policy according to the backyard swine producer is required and that NOM-001-ECOL-1996 is not sufficient to regulate this production, mainly due to the lack of budget and personnel for monitoring unregistered units.

\section{CONCLUSIONS}

In order to care for the environment and water resources, it is important to identify and evaluate the effects of backyard production in rural areas. The main reason for the problem is the lack of knowledge of proper swine management practices and environmental awareness by small producers, as well as the lack of capacity and skills to treat the waste generated by the activity. Therefore, environmental policies must be created to support training and technical assistance for small producers in environmental issues, not just production issues, which should be implemented through social agricultural extension programs and regulated with new control instruments adapted to the size of the small producer.

\section{REFERENCES}

Clark, C. M., \& Tilman, D. (2008). Loss of plant species after chronic low-level nitrogen deposition to prairie grasslands. Nature, 451 (7179), p.712-715. https://doi.org/10.1038/nature06503

De la Mora, C., Saucedo, T. R. A., Barrientos, J. E., Gómez, R. S., González, A. I. J., \& Domínguez, A. G. (2014). Humedales artificiales para el tratamiento de aguas residuales provenientes de granjas porcícolas. Instituto Nacional de Investigaciones Forestales, Agrícolas y Pecuarias.

Di Iorio, J., Universidad de Buenos Aires, Seidmann, S., Rigueiral, G. y Abal, Y. (2020). Circuitos Socio-Asistenciales para Población en Situación de Calle en la Ciudad de Buenos Aires: Representaciones Sociales y Prácticas. Psykhe (Santiago), 29 (1), 1-13p.

Escalante Semerena, RI, Drucker, AG, Gómez González, V. \& Magaña Rueda, S. (2009). La industria porcina en Yucatán: un análisis de la generación de aguas residuales. Problemas del desarrollo, 34 (135). 105-124p. Doi: doi:10.22201/ iiec.20078951e.2003.135.7505

FAOCC. (2020). Padrón de productores agremiados a la Fundación Autónoma de Organizaciones de Campesinos y Colonos del estado de Veracruz.

Liu, X. J., Zhang, Y., Han, W. X., Tang, A. H., Shen, J. L., Cui, Z. L., Vitousek, P., Erisman, J. W., Goulding, K., Christie, P., Fangmeier, A., \& Zhang, F. S. (2013). Enhanced nitrogen deposition over China. Nature, 494 (7438), 459-462p. https://doi.org/ https://doi.org/10.1038/nature11917

Mariscal, G. (2007). Tratamiento Excretas Cerdos. FAO, Producción Porcina, 1-9p. www.fao.org/wairdocs/LEAD/X6372S/x6372s08. htm 
Mateo, N., Nani, G., Montiel, W., Nakase, C., \& Salazar-salazar, C. (2019). Efecto de Canna hybrids en humedales construidos parcialmente saturados para el tratamiento de aguas porcinas. Revista Internacional de Desarrollo Rural Sustentable, 4(4), 59-68p.

Méndez, R., Castillo Borges, E., Vázquez Borges, E., Briceño Pérez, O., Coronado Peraza, V., Pat Canul, R., Garrido Vivas, P., \& Vivas, R. G. (2009). Estimación del potencial contaminante de las granjas porcinas y avícolas del estado de Yucatán. Ingeniería, 13 (2), 13-21p.

Méndez-López, J. M., Rodríguez, O. L., Mandujano, C. J. C., Reyes, C., \& Banda, I. H. (2016). Yuke: Alimento alternativo para cerdos a base de yuca: Determinando su rentabilidad y viabilidad económica. Revista Global de Negocios, 4(7), 53-62p.

Olivier, J. G. J., Bouwman, A. F., \& VanderHoek, K.W. Berdowski, J. J. M. (1998). Global air emission inventories for anthropogenic sources of $\mathrm{NO}_{\mathrm{X}}, \mathrm{NH}_{3}$ and $\mathrm{N}_{2} \mathrm{O}$ in 1990. Environmental Pollution, 102 (1), p135-148p. https://doi.org/10.1016/S02697491(98)80026-2

Osejos, M., Jaramillo, J., Merino, M., Quimis, A., \& Alcívar, J. (2018). Producción de biogás con estiércol de cerdo a partir de un biodigestor en la Granja EMAVIMA Jipijapa. Dominio de Las Ciencias, 4, (1) p.709-733 p. DOI: 10.23857/dc.v4i1.788

Sandoval-Herazo, M., Nani, G., Sandoval, L., Rivera, S., Fernández-Lambert, G., \& Alvarado-Lassman, A. (2020). Evaluación del desempeño de humedales construidos verticales parcialmente saturados para el tratamiento de aguas residuales porcinas. Tropical and Subtropical Agroecosystems, 38(23), p.14.

Taiganides, P. E., Pérez, R., \& Girón, E. (2000). Manual para el manejo y control de aguas residuales y excretas porcínas en México, México. Consejo Mexicano de Porcicultura, 29 p. 